\title{
Design of antiseptic formulations containing extract of Plinia cauliflora
}

\author{
Lara Alexandre de Oliveira ${ }^{1,2}$, Tatiana Maria de Souza-Moreira ${ }^{2}$, Letícia Caramori Cefali ${ }^{2}$, \\ Bruna Galdorfini Chiari², Marcos Antonio Corrêa², Vera Lucia Borges Isaac², \\ Hérida Regina Nunes Salgado², Rosemeire Cristina Linhari Rodrigues Pietro ${ }^{2, *}$
}

\author{
${ }^{1}$ Faculty of Pharmacy, University Center of Araraquara, UNIARA, \\ ${ }^{2}$ Faculty of Pharmaceutical Sciences, São Paulo State University, UNESP
}

\begin{abstract}
The leaves of the Brazilian species Plinia cauliflora were used to obtain active hydroalcoholic extract and fractions enabling the development of efficient antiseptic pharmaceutical formulations. A chemical composition of $70 \%$ ethanol extract, aqueous and ethyl acetate fractions was analyzed by thin-layer chromatography and for phenol content. Antimicrobial activity was tested against Staphylococcus aureus, Staphylococcus epidermidis, Escherichia coli, Lactobacillus acidophilus and Candida albicans by the agar diffusion method and the minimum inhibitory concentration was assayed by broth microdilution. Extract microbiological quality was tested to avoid contamination in the formulations. A mouthwash and a topical cream containing the extract were developed and antiseptic activity was assessed by agar diffusion. Sensory and physicochemical stability of the formulations were assayed. Chromatography indicated the presence of terpenes, flavonoids and tannins in the extract and fractions and total phenol content were found to be high. The plant samples were active against all the microorganisms tested, except for Lactobacillus acidophilus. Both topical formulations showed antiseptic activity and stability. Thus, these may be used as antimicrobials in skin infections, but would be more useful in the treatment of candidiasis.
\end{abstract}

Uniterms: Antiseptic formulations/design. Plinia cauliflora/antimicrobial activity. Plinia cauliflora/ antiseptic activity. Mouthwash. Plant extract. Topical cream.

As folhas da espécie brasileira Plinia cauliflora foram utilizadas a fim de se obter um extrato hidroalcoólico e frações ativas proporcionando o desenvolvimento de eficazes formulações farmacêuticas antissépticas. A composição química do extrato etanólico $70 \%$, fração aquosa e acetato de etila foi analisada por cromatografia em camada delgada e teor de fenóis. A atividade antimicrobiana foi testada frente a Staphylococcus aureus, Staphylococcus epidermidis, Escherichia coli, Lactobacillus acidophilus e Candida albicans por difusão em ágar e a concentração inibitória mínima foi determinada por microdiluição. A qualidade microbiológica do extrato foi avaliada para evitar a contaminação das formulações. Foram desenvolvidos um enxaguatório bucal e um creme tópico contendo o extrato sendo que a atividade antisséptica foi ensaiada por difusão em ágar. A estabilidade sensorial e físico-química foram testadas. A cromatografia indicou a presença de terpenos, flavonóides e taninos no extrato e frações, observando-se alto teor de fenóis totais. As amostras vegetais foram ativas contra todos os microorganismos testados, exceto Lactobacillus acidophilus. Ambas as formulações apresentaram atividade antisséptica e estabilidade. Desta forma, infere-se que as formulações desenvolvidas podem ser utilizadas como antissépticas em infecções de pele, podendo ser mais eficazes no tratamento de candidíase.

Unitermos: Formulações antissépticas/planejamento. Plinia cauliflora/atividade antimicrobiana. Plinia cauliflora/atividade antisséptica. Enxaguatório bucal. Extrato vegetal. Creme tópico.

\footnotetext{
*Correspondence: R. C. L. R. Pietro. Department of Drugs and Medicines, School of Pharmaceutical Sciences, São Paulo State University - UNESP. Rod. Araraquara-Jaú km 1 - 14801-902 - Araraquara - SP, Brazil. E-mail: pietrorc@ fcfar.unesp.br
} 


\section{INTRODUCTION}

Antimicrobial agents have been used since the seventeenth century for the treatment of infectious diseases. Over the past 20 years, there has been a growing interest in screening natural products as a potential source of new antimicrobial substances (Silva et al., 2005; Suffredini et al., 2006). The antimicrobial properties of many substances extracted from plants have been scientifically proven. Thus, research conducted in several countries, including Brazil, where the plant diversity is exceptional, has shown a variety of substances to be effective in controlling the growth of microorganisms, as reported in the work of Pessini et al. (2003), Souza et al. (2003), Fiuza et al. (2008) and many others.

Plinia cauliflora (Mart.) Kausel is a tree of the Myrtaceae family, widely distributed in Brazil, where its popular edible fruit is known as jaboticaba and the bark is used as a source of astringent (Lorenzi, 2000). This tree occurs in alluvial plains and open rain forests, being found in forests in Brazil, Argentina and Paraguay. P. cauliflora produces abundant delicious fruits two or more times a year (Barros et al., 1996; Lorenzi, 2000). The bark is astringent and used by Brazilians to treat diarrhoea and skin irritations (Lorenzi, 2000). Extracts of the leaves were shown to have antimicrobial activity in previous work (Souza-Moreira et al., 2010). These promising results prompted this study to assess the antimicrobial activity of extracts and fractions from leaves of Plinia cauliflora against several species of microorganisms and to develop a topical cream for skin and genital administration as well as a mouthwash containing the extract, which should be effective, stable and of good quality.

Some mouthwashes are responsible for reducing the microbial load in the oral cavity (Shapiro et al., 2002). Bacterial and fungal infections are prevalent in critically ill and immunocompromised patients, and there is a high prevalence of oral candidiasis in immunocompromised patients and patients with dentures (Abu-Elteen and AbuAlteen, 1998; Webb et al., 1998), especially when denture hygiene is poor (Webb et al., 2005). Alcohol and chlorhexidine are frequently used as oral cavity antimicrobials but show significant irritant potential. Sensitive and inflamed mucosa, especially that of cancer, is more susceptible to the unpleasant taste and irritant property of these products (Bahna et al., 2007).

Creams are well tolerated formulations because they interact mildly with the skin (Xhauflaire-Uhoda et al., 2008). They provide a barrier effect and improve permeation of active compounds into the human epidermis. Several topical formulations were prepared with Melaleu- ca alternifolia essential oil, a potent antimicrobial agent, at concentrations up to 5\% (Biju et al., 2005; Reichling et al., 2006). Emulsion, ointment and cream proved to enhance essential oil permeation through the skin where this is important in the treatment of some subcutaneous infections such as candidiasis (Reichling et al., 2006).

The purpose of the present study was to develop, for the first time, two antiseptic phytopharmaceutical formulations with extract of the Brazilian native leaves of $P$. cauliflora to help control infections in oral and vaginal mucous membranes.

\section{MATERIAL AND METHODS}

\section{Media, chemicals and reagents}

Brain-Heart Infusion broth, Sabouraud broth, Sabouraud Dextrose agar and microbiological quality control media besides agar were acquired from Acumedia (Lansing, Michigan, USA); MRS broth was acquired from Fluka (Steinheim, Switzerland); Müeller Hinton agar was acquired from Himedia (Mumbai, India) and RPMI-1640 broth was acquired from Sigma (St. Louis, Missouri, USA). Solvents (glycerol, ethanol, ethyl acetate, chloroform, methanol, $n$-propanol, dimethyl sulfoxide, propylene glycol, sorbitol), glucose, sodium saccharine and $p$-anysaldehide-sulphuric acid were purchased from Labsynth (Diadema, São Paulo, Brazil). Emulsifying wax and methylparaben were obtained from Volp (Osasco, São Paulo, Brazil); grape seed oil and propylparaben were obtained from Deg (São Paulo, São Paulo, Brazil); octyl stearate and carbomer were acquired from PharmaSpecial (Santana de Parnaíba, São Paulo, Brazil); and butylhydroxy toluene was acquired from Makeni Chemicals (Diadema, São Paulo, Brazil). The Folin-Ciocalteau reagents were obtained from Imbralab (Ribeirão Preto, São Paulo, Brazil); tannic acid was acquired from Ecibra (Santo Amaro, São Paulo, Brazil); sodium carbonate, resazurin and 2,3,5-triphenyltetrazolium were obtained from Vetec (Duque de Caxias, Rio de Janeiro, Brazil).

\section{Microorganisms}

The following reference strains were used in the study: Staphylococcus aureus ATCC 25923, Staphylococcus epidermidis ATCC 12228, Escherichia coli ATCC 10536, Lactobacillus acidophilus INCQS 00076 and Candida albicans ATCC 64548. Bacteria were maintained in Brain-Heart Infusion (BHI) broth and L. acidophilus in MRS broth, both containing $20 \%$ (v/v) glycerol at $-20^{\circ} \mathrm{C}$. Before testing, the bacteria were transferred to fresh BHI 
medium and left to grow aerobically for $24 \mathrm{~h}$ at $37^{\circ} \mathrm{C}$. The inocula for the tests were prepared by diluting these bacterial suspensions in saline to the turbidity of the $0.5 \mathrm{McF}$ arland standard $\left(10^{8} \mathrm{CFU} \mathrm{mL}^{-1}\right)$ (CLSI, 2003a), except in the case of $L$. acidophilus, which was diluted to match the $5 \mathrm{McF}$ arland standard $\left(10^{9} \mathrm{CFU} \mathrm{mL}^{-1}\right)$ (Ocaña et al., 2006). C. albicans was maintained by culturing on Sabouraud Dextrose Agar (SDA) and, for the tests, transferred to Sabouraud broth and grown at $35^{\circ} \mathrm{C}$ for $48 \mathrm{~h}$. The inoculum was prepared by adjusting the suspension turbidity to match the $0.5 \mathrm{McF}$ arland standard $\left(10^{6} \mathrm{CFU} \mathrm{mL}^{-1}\right)$, in saline (CLSI, 2009).

\section{Plant material}

Leaves of Plinia cauliflora were collected in São Carlos city, state of São Paulo (22001'16.6” N, 47 53'57.0” W). Specimens of this species were identified by Marcos Sobral and a copy was deposited in the herbarium of Escola Superior de Agricultura "Luiz de Queiroz" (ESALQ), USP at Piracicaba (São Paulo, Brazil) (ESA No. 96038).

\section{Preparation of leaf extract and fractions}

The leaves were dried for four days at $40{ }^{\circ} \mathrm{C}$, powdered in a knife mill and stored. The dried and powdered leaves of $P$. cauliflora were extracted to exhaustion with $70 \%$ ethanol (v/v) in a percolating apparatus at room temperature (Farmacopéia Brasileira, 1988). The extract was dried under reduced pressure at $40{ }^{\circ} \mathrm{C}$ and weighed. This extract was subjected to liquid-liquid partition with water and ethyl acetate. The fractions were dried under reduced pressure at $40{ }^{\circ} \mathrm{C}$ and weighed.

\section{Pharmacognostic analysis}

Thin-layer chromatography: Preliminary pharmacognostic analysis was performed by comparative thin-layer chromatography (TLC), applying the 70\% ethanol extract and fractions to a silica gel $60 \mathrm{~F}_{254}$ plate. The mobile phase consisted of the organic phase of chloroform:methanol: $n$-propanol:water $(5: 6: 1: 4, \mathrm{v} / \mathrm{v})$. The spots were observed under UV and visible light and after being sprayed with $p$-anisaldehyde-sulfuric acid reagent.

Phenolics content: Total phenolic compounds in the extract were determined by the Folin-Ciocalteau method (1927), adapted by Monteiro et al. (2006). Results were expressed in terms of a standard curve for tannic acid. To prepare this, several aliquots of a $1.0 \mathrm{mg} \mathrm{mL}^{-1}$ tannic acid aqueous solution were diluted in $7.5 \mathrm{~mL}$ of distilled water, $0.5 \mathrm{~mL} \mathrm{10 \%} \mathrm{Folin-Ciocalteau} \mathrm{reagent} \mathrm{and} 1.0 \mathrm{~mL}$
$0.75 \% \mathrm{Na}_{2} \mathrm{CO}_{3}$ were added and the volume completed to $10 \mathrm{~mL}$ with water. Extract was treated similarly, but to a final concentration of $10 \mu \mathrm{g} \mathrm{mL}^{-1}$. After $3 \mathrm{~h}$, the absorbance was measured at $760 \mathrm{~nm}$ with a Shimadzu UV-1603 spectrophotometer.

\section{Microbiological quality control of the extract}

In order to avoid further contamination in the formulations the extract microbiological assay was performed. The numbers of viable aerobic microorganisms (Salmonella sp, Escherichia coli, Pseudomonas aeruginosa and Staphylococcus aureus) in the extract were determined by methods recommended by the Farmacopeia Brasileira (1988) and Pinto et al. (2003), performed in triplicate.

\section{Agar diffusion method}

Bacteria: Except for lactobacilli, the test was performed in Müller Hinton agar (MHA) following the Guideline M2-A8 from the Clinical and Laboratory Standards Institute (CLSI, 2003a). Plates were seeded separately, with each bacterial cell suspension at $1 \%(\mathrm{v} / \mathrm{v})$, giving

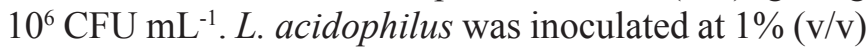
$\left(10^{7} \mathrm{CFU} \mathrm{mL} \mathrm{mL}^{-1}\right)$ in MRS agar (Ocaña et al., 2006).

Yeast: The test was performed in MHA supplemented with $0.05 \mathrm{mg} \mathrm{mL}^{-1}$ methylene blue and $2 \%$ glucose, inoculated with $1 \%$ of the cell suspension $\left(10^{4} \mathrm{CFU} \mathrm{mL}^{-1}\right)$ as in Guideline M44-A2 from the CLSI (2009). In all tests, a steel template was placed on the seeded agar and separately, in each $6 \mathrm{~mm}, 100 \mu \mathrm{L}$ of the extract, ethyl acetate fraction or aqueous fraction was added at a concentration of $50 \mathrm{mg} \mathrm{mL}^{-1}$, in dimethyl sulfoxide (DMSO) diluted in saline $(1: 5, \mathrm{v} / \mathrm{v}$, or $100 \mu \mathrm{L}$ of the positive control: ampicillin $\left(50 \mu \mathrm{g} \mathrm{mL}^{-1}\right)$ for all bacteria and amphotericin B (64 $\left.\mu \mathrm{g} \mathrm{mL}^{-1}\right)$ for yeast. A negative solvent control, DMSO:BHI $(1: 5, \mathrm{v} / \mathrm{v})$, was also used on all plates. The tests were performed in triplicate.

\section{Broth microdilution method}

Minimum inhibitory concentrations (MIC) were determined as recommended in Guidelines M7-A6 of the Clinical and Laboratory Standards Institute (CLSI, 2003b) for bacteria and M27-A2 for yeast (CLSI, 2002). The test was performed in sterile 96-well microplates. The test solutions of extract and fractions in DMSO:medium $(1: 10 \mathrm{v} / \mathrm{v})$ were transferred to microplate wells so as to obtain twofold serial dilutions in a concentration range from 2.5 to $0.039 \mathrm{mg} \mathrm{mL}^{-1}$, with diluted ampicillin from 12.5 to $0.019 \mu \mathrm{g} \mathrm{mL}^{-1}$ and amphotericin B from 16 to $0.01 \mu \mathrm{g} \mathrm{mL}^{-1}$, 
as positive controls. The inocula $(100 \mu \mathrm{L})$, containing $2.5 \times 10^{5} \mathrm{CFU} \mathrm{mL}^{-1}$ of bacteria or $2.5 \times 10^{3} \mathrm{CFU} \mathrm{mL}^{-1}$ of yeast (in BHI or RPMI-1640 broth),were added to each well. A number of wells were reserved in each plate to check sterility (without inoculum), inoculum viability (without extract) and DMSO inhibitory effect. Plates were incubated aerobically with shaking ( 100 rotates per min) at $35^{\circ} \mathrm{C}$, for $24 \mathrm{~h}$ for bacteria and $48 \mathrm{~h}$ for yeast. After incubation, microbial growth was observed by the addition of a $0.5 \%$ aqueous solution of resazurin for bacteria and $1 \%$ aqueous solution of 2,3,5-triphenyltetrazolium for yeast. MIC was defined as the lowest concentration that inhibited growth (Gabrielson et al., 2002; Duarte et al., 2005). The minimum bactericidal and fungicidal concentrations (MBC and MFC) were determined by subculturing from microplate wells on MHA and Sabouraud agar plates, respectively, which were incubated for $24 \mathrm{~h}$ at $37^{\circ} \mathrm{C}$ for bacteria and $48 \mathrm{~h}$ at $35^{\circ} \mathrm{C}$ for yeast. MBC and MFC were the lowest concentrations without viable cells. The tests were performed in triplicate.

\section{Formulation preparation}

In the topical cream $(\mathrm{O} / \mathrm{W})$ formula, the following materials were used: emulsifying wax $(1.5 \%)$, octyl stearate $(2.0 \%)$, grape seed oil $(2.0 \%)$, methylparaben $(0.002 \%)$, propylparaben $(0.018 \%)$, butylhydroxy toluene $(0.02 \%)$, propylene glycol $(4.0 \%)$, carbomer $(30 \%)$, extract of $P$. cauliflora $(0.25 \%)$ and aqua q.s. $100 \%$ by weight. The extract was incorporated in the cream at $40{ }^{\circ} \mathrm{C}$ and homogenized. The mouthwash was prepared from the following materials: sorbitol (3.0-5.0\%), methylparaben $(0.20 \%)$, sodium saccharin (q.s.), extract of $P$. cauliflora $(0.25 \%)$ and aqua q.s. $100 \%$. Extract of Plinia cauliflora was dissolved in sorbitol and incorporated into the prepared solution of mouthwash. The concentration of extract used in these preparations was determined from the MIC values. The cream and mouthwash were also prepared without the extract, for comparison with the activity of antiseptic preparations containing extract.

\section{Determination of antimicrobial activity of pharmaceutical formulations}

The antiseptic activity of preparations was tested by the agar diffusion method. The density of microorganisms and preparation of the plates were as in the test for antimicrobial activity described above. The mouthwash samples $(200 \mu \mathrm{L})$ were placed in steel templates on the solidified inoculated agar (Ocaña et al., 2006), but the samples of topical cream were added by the pour-plate method in the culture medium. Tests were performed on the mouthwash with and without extract and the topical cream with and without extract. The positive controls were ampicillin $\left(50 \mu \mathrm{g} \mathrm{mL}^{-1}\right)$ for bacteria and amphotericin B $\left(64 \mu \mathrm{g} \mathrm{mL}^{-1}\right)$ for yeast. The plates were incubated for $24 \mathrm{~h}$ at $37^{\circ} \mathrm{C}$ for bacteria and $48 \mathrm{~h}$ at $35^{\circ} \mathrm{C}$ for yeast. All tests were performed in triplicate and the mean diameters of the inhibition zones were recorded.

\section{Physical stability tests}

Physical stability was tested by subjecting the formulations to storage at $5 \pm 2{ }^{\circ} \mathrm{C}$, at $45 \pm 2{ }^{\circ} \mathrm{C}$ and exposed to light at room temperature, with a control at room temperature $\left(27 \pm 2{ }^{\circ} \mathrm{C}\right)$. Samples from each formulation container were tested at the start and after 1, 7, 15, 30, 60 and $90 \mathrm{~d}$, by the following methods (Isaac et al., 2008; Ordoñez et al., 2009):

Centrifugation assays: Five grams of each sample was centrifuged three times at $3000 \mathrm{rpm}$ for $30 \mathrm{~min}$ each time. Subsequently, preparations were placed in opaque containers and stored under the stress conditions described above.

pH measurements: One gram of each formulation was weighed and diluted to $10 \mathrm{~mL}$ with distilled water. The mixture was homogenized and its $\mathrm{pH}$ measured with a $\mathrm{pH}$ meter. All measurements were made at room temperature in triplicate for each analyzed sample.

Sensory properties: Color, odor and appearance were monitored at the same time intervals as the other parameters.

Viscosity: Minimum apparent viscosity was determined with a cone and plate Haake rheometer (Rheostress 1), equipped with a recirculating water-bath, to control the sample container temperature, and Rhcowin-3 software. Viscosity was measured at progressively higher shear rates (speed of rotation $0-100 \mathrm{~s}^{-1}$ ) for the upward curve and the procedure was repeated in reverse, with progressively slower rates $\left(100-0 \mathrm{~s}^{-1}\right)$ for the descending curve, both for $120 \mathrm{~s}$. All tests were performed in triplicate for each sample analyzed.

\section{Statistical analysis}

The results are expressed as mean \pm SD. MIC, MBC and MFC are expressed as mode values. Statistical significance was tested using Student's t test. A difference was taken to be significant at $P<0.05$.

\section{RESULTS}

The present study was conducted to investigate the antimicrobial activity of $P$. cauliflora leaf extract and 
fractions and to use this extract to prepare pharmaceutical formulations with antimicrobial properties. The extract was chosen for its good activity (Souza-Moreira et al., 2010) and with the aim of providing cheaper formulations.

The dried $70 \%$ ethanol extract and its aqueous and ethyl acetate fractions yielded $24 \mathrm{~g}, 1.65 \mathrm{~g}$ and $4.22 \mathrm{~g}$, respectively. The TLC indicated the presence of terpenes, flavonoids and tannins in the hydroethanolic extract, as described in the work of Souza Moreira et al. (2010). Tannins were mainly found in the aqueous fraction and terpenes and flavonoids in the ethyl acetate. The extract showed $70 \%$ phenolic content.

The microbiological quality control showed that there was no growth of the four pathogenic microorganisms, Salmonella, E. coli, S. aureus and P. aeruginosa, in the leaf extract. The total viable count of microorganisms was $17 \mathrm{CFU} \mathrm{g}^{-1}$ of extract, which allows its approval, according to the official limit of not more than $5 \times 10^{3} \mathrm{CFU} \mathrm{g}^{-1}$ or $\mathrm{mL}$ for non-sterile products (Farmacopeia Brasileira, 1988).

In the agar diffusion tests, the aqueous fraction and whole extract were the samples that showed the best antimicrobial activity against the bacterium $S$. aureus and the yeast Candida albicans, while the acetate fraction showed the smallest inhibition zones (Table I). No samples showed inhibitory activity against Lactobacillus acidophilus. Table I also shows the values of MIC, MBC and MFC for the extract and fractions. It can be seen that the yeast was more sensitive, with smaller MICs, although the minimum fungicidal concentrations were higher. The negative control using only DMSO did not inhibit the microbial growth.

The preparations were formulated with crude extract as antiseptic agent, not as preservative agent. Though not the best inhibition zones, the extract showed considerable antiseptic activity and was chosen since this material was much cheaper than the fractions. The topical cream and mouthwash containing the extract proved to be effective antiseptics in the agar diffusion tests, against all four microorganisms tested, as shown in Table II. Control preparations without extract did not show growth inhibition zone so they are not shown in Table II. A product is classed as an antiseptic when it produces an inhibition zone of $8 \mathrm{~mm}$ or more (using steel templates with $6 \mathrm{~mm}$ diameter wells) (Roessler, 1983).

Preparations showed no phase separation when centrifuged repeatedly and their sensory parameters of appearance, color and odor did not change throughout the period of exposure to stress conditions. Moreover, no significant changes in physical and chemical properties were observed, attesting to the stability of the preparations of topical cream and mouthwash with the extract of P. cauliflora.

The initial $\mathrm{pH}$ of the mouthwash and the topical cream was 6.50 . These values did not vary by more than 0.5 during the period under stress conditions so that the $\mathrm{pH}$ remained compatible with mucosal and cutaneous $\mathrm{pH}$

TABLE I - Antimicrobial activity of extract and fractions from leaves of $P$. cauliflora

\begin{tabular}{|c|c|c|c|c|c|c|c|c|c|c|c|c|c|c|c|}
\hline \multirow{2}{*}{$\begin{array}{l}\text { Microorganism } \\
\text { Sample }\end{array}$} & \multicolumn{3}{|c|}{ S. aureus } & \multicolumn{3}{|c|}{ S. epidermidis } & \multicolumn{3}{|c|}{ E.coli } & \multicolumn{3}{|c|}{ L. acidophilus } & \multicolumn{3}{|c|}{ C. albicans } \\
\hline & Zone* & $\mathrm{MIC}^{\dagger}$ & $\mathrm{MBC}^{\dagger}$ & Zone & MIC & $\mathrm{MBC}$ & Zone & MIC & $\mathrm{MBC}$ & Zone & MIC & $\mathrm{MBC}$ & Zone & MIC & $\mathrm{MFC}^{\dagger}$ \\
\hline Extract & $\begin{array}{c}12.36 \pm \\
2.38\end{array}$ & 1250 & $>2500$ & $\begin{array}{c}11.97 \pm \\
3.46\end{array}$ & 2500 & 2500 & $\begin{array}{c}11.45 \pm \\
1.63\end{array}$ & 2500 & 2500 & 0 & $\mathrm{NA}^{\ddagger}$ & NA & $\begin{array}{c}15.36 \pm \\
3.40\end{array}$ & 156 & $>2500$ \\
\hline $\begin{array}{l}\text { Aqueous } \\
\text { fraction }\end{array}$ & $\begin{array}{c}18.62 \pm \\
3.80\end{array}$ & 1250 & 2500 & $\begin{array}{c}11.14 \pm \\
1.32\end{array}$ & 1250 & $>2500$ & $\begin{array}{c}13.25 \pm \\
2.56\end{array}$ & 2500 & 2500 & 0 & NA & NA & $\begin{array}{c}15.91 \pm \\
3.78\end{array}$ & 78 & $>2500$ \\
\hline $\begin{array}{l}\text { Ethyl acetate } \\
\text { fraction }\end{array}$ & $\begin{array}{c}13.85 \pm \\
2.08\end{array}$ & 1250 & $>2500$ & $\begin{array}{c}10.58 \pm \\
0.40\end{array}$ & 1250 & 1250 & $\begin{array}{c}13.11 \pm \\
0.70\end{array}$ & 2500 & 2500 & 0 & NA & NA & $\begin{array}{c}12.05 \pm \\
3.24\end{array}$ & 312 & $>2500$ \\
\hline
\end{tabular}

\footnotetext{
* inhibition zone $(\mathrm{mm}) \pm$ standard deviation.

$\dagger \mathrm{MIC}, \mathrm{MBC}$ and MFC values in $\mathrm{mg} \mathrm{mL}^{-1}$.

ॠA: not applicable.
} 
TABLE II - Growth inhibition zones of antiseptic preparations developed

\begin{tabular}{lccc}
\hline Microorganisms & $\begin{array}{c}\text { Topical } \\
\text { cream }\end{array}$ & Mouthwash & $\begin{array}{c}\text { Antimicrobial } \\
\text { control }\end{array}$ \\
\hline S. aureus & $21.45 \pm 1.88^{*}$ & $15.27 \pm 0.87$ & $22.32 \pm 2.52$ \\
S. epidermidis & $18.27 \pm 0.75$ & $16.61 \pm 5.23$ & $22.38 \pm 1.64$ \\
E.coli & $22.78 \pm 1.32$ & $15.26 \pm 0.48$ & $22.91 \pm 2.96$ \\
C. albicans & $20.81 \pm 2.40$ & $20.55 \pm 4.80$ & $20.74 \pm 1.49$ \\
\hline
\end{tabular}

* Mean inhibition zone diameters $(\mathrm{mm}) \pm$ standard deviations

and the formulations could be considered stable (Isaac et al., 2008).

The results of the viscosity tests can be seen in Figure 1 for the mouthwash (A) and for the topical cream (B).

It was observed that the viscosity of the emulsion (Figure 1 (B)) decreased slightly from initial value when subjected to stress conditions, but the overall variation was less than $10 \%$ and the emulsion is thus considered stable, according to Isaac et al. (2008). No significant change was observed in the viscosity of mouthwash (Figure 1 (A)). Its value was close to zero, as the main constituent of the formulation was water, which has this viscosity profile (Schramm, 2006). Since viscosity is a physicochemical parameter that reveals the flow properties of a fluid (Schramm, 2006), it was concluded that both preparations were stable with respect to this property.

\section{DISCUSSION}

In an early comparative study of the antioxidant and antimicrobial activities of 50\% ethanol, $70 \%$ ethanol, acetone:water $(7: 3, \mathrm{v} / \mathrm{v})$ and chloroform extracts obtained from the leaves of $P$. cauliflora by percolation, the best results were shown by the non-apolar extracts (SouzaMoreira et al., 2010). Some phytochemical characterization and biological activity were described previously by

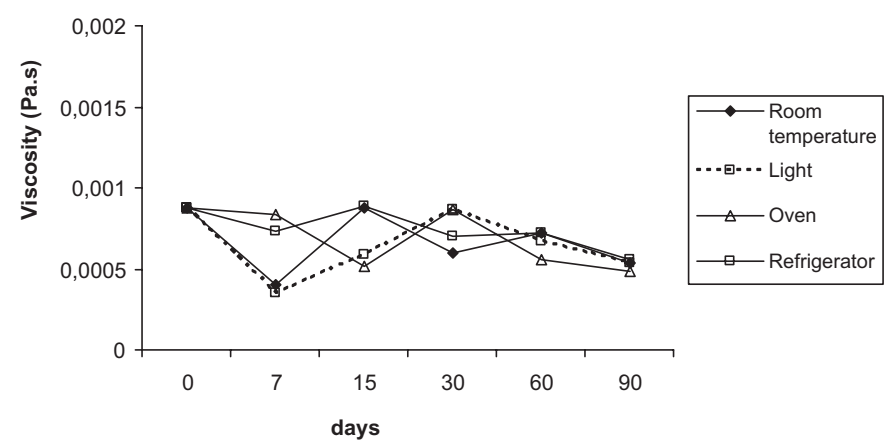

Souza-Moreira et al. (2010) while the present study has reproduced the standardized obtention of the $70 \%$ extract and provided pharmaceutical formulations confirming the activity of the extract in topical products.

Chemical compositions of the extract and fractions were confirmed by TLC and quantitative analysis. Choi et al. (2006) suggested that many biological activities in plants are due to the content of total phenols, such as flavonoids and tannins. The quantitative analysis of phenolic compounds demonstrated that the $70 \%$ ethanol extract of P. cauliflora standardized as $70 \%$ phenolic compounds may be sufficient to produce an inhibitory effect on the growth of pathogenic bacteria and yeasts.

The extract showed no growth of the specific pathogenic microorganisms and a low total viable count of microorganisms, ensuring that the microbial load in the final product does not lower its quality or endanger the patient (Pinto et al., 2003).

Serafin et al. (2007), working with Plinia glomerata leaves, found MIC values for the aqueous and ethyl acetate fractions ranging from 500 to $1000 \mu \mathrm{g} \mathrm{mL}^{-1}$ against $E$. coli and $S$. aureus, whereas against $C$. albicans the aqueous fraction had a MIC of $250 \mu \mathrm{g} \mathrm{mL}^{-1}$, showing that this yeast was more susceptible than the bacteria, as in the present study of the leaf extract of $P$. cauliflora, belonging to the same genus.

An important issue to be considered in relation to the fight against infection is the maintenance of the normal bacterial population in people, such as Lactobacillus spp bacteria in the human vaginal mucosa, which can protect against pathogens (Sobel, 2000; Reid, 2003; Andreu, 2004) by producing acids, hydrogen peroxide, bacteriocins and biosurfactants (Hillier et al., 1992). Since in this study the yeast $C$. albicans showed a greater susceptibility to the extract, it was especially interesting to note that the exemplary vaginal microorganism, L. acidophilus, was not sensitive to the plant extract, which may justify the development of pharmaceutical formulations containing

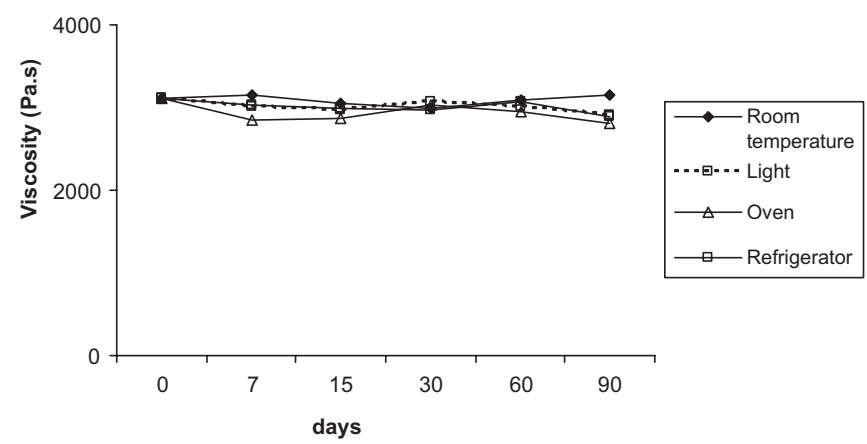

FIGURE 1 - Viscosity of the mouthwash (A) and of the topical cream (B) containing extract, subjected to stress conditions over 90 days. 
extract or fractions of leaves of $P$. cauliflora to assist in the treatment of candidiasis by acting on the pathogen without disturbing the balance of the mucosal microbiota. Also, it was observed that the formulations provided antisepsis against the microorganisms tested, especially against the yeast. Candida albicans is a common commensal microorganism in skin and the genital area, but becomes pathogenic under predisposing conditions. To treat skin and the genital area it was important to develop a viscous topical cream with the active extract (Calderone, 2002). Another interesting finding of the present work is that, while $M$. alternifolia essential oil is used in creams at $5 \%$ (Biju et al., 2005; Reichling et al., 2006), the present study showed an efficient antiseptic formulation using $0.25 \%$ of a vegetal sample.

Cordeiro et al. (2006) observed that mouthwashes containing the plant species Rosmarinus officinalis, Plantago major, Tabebuia impetiginosa, Achillea millefolium and Nasturtium officinale also showed some activity, but there was no difference between the results produced by the mouthwashes with or without the plant extracts at $2 \%$ or $4 \%$, while in our study a clear difference can be seen between the mouthwash containing the extract at $0.25 \%$ and the control.

Besides effectiveness, it is necessary to assess the stability of a formulation. The stability study provides information on the performance of the product after any given time intervals, taking into account the environmental conditions to which it may be subjected from production to expiry date (Isaac et al., 2008). In the accelerated stability test, it was observed that the formulations did not change significantly when subjected to stress conditions. Thus, these preparations show promise for the treatment of infections, especially candidiasis, since they possess activity against several pathogens, but none against the lactobacilli present in the normal mucosal microbiota, and are within the reference limits of quality and stability.

\section{ACKNOWLEDGMENTS}

The authors acknowledge the technical assistance of Luis Eduardo dos Santos and Maria de Fátima Rodrigues and the financial support of FAPESP and PADC-UNESP.

\section{REFERENCES}

ABU-ELTEEN, K. H.; ABU-ALTEEN, R. M. The prevalence of Candida albicans populations in the mouths of complete denture wearers. New Microb., v.21, n.1, p.41-48, 1998.
ANDREU, A. Lactobacillus as a probiotic for preventing urogenital infections. Rev. Med. Microbiol., v.15, n.1, p.16, 2004.

BAHNA, P.; HANNA, H. A.; DVORAK, T.; VAPORCIYAN, A.; CHAMBERS, M.; RAAD, I. Antiseptic effect of a novel alcohol-free mouthwash: A convenient prophylactic alternative for high-risk patients. Oral Oncol., v.43, n.2, p.159-164, 2007.

BARROS, R. S.; FINGER, F. L.; MANGALHÃES, M. M. Changes in nonstructural carbohydrates in developing fruit of Myrciaria jaboticaba. Sci. Hortic., v.66, n.3-4, p.17-22, 1996.

BIJU, S. S.; AHUJA, A.; RAFIULLAH, M. R. M.; KHAR, R. K. A validated HPTLC method for determination of tea tree oil from cosmeceutical formulations. J. Pharm. Biomed. Anal., v.38, n.1, p.41-44, 2005.

CALDERONE, R.A. Candida and candidiasis. Washington, DC: ASM Press, 2002. 450 p.

CHOI, Y. M.; NOH, D. O.; CHO, S. Y.; SUH, H. J.; KIM, K. M.; KIM, J. M. Antioxidant and antimicrobial activities of propolis from several regions of Korea. $L W T$, v.39, n.7, p.756-761, 2006.

CLINICALAND LABORATORY STANDARDS INSTITUTE (CLSI). Reference method for testing broth dilution for the determination of sensitivity to antifungal therapy of yeast. 2.ed. Wayne: Clinical and Laboratory Standards Institute, 2002. (Approved Standard M27-A2).

CLINICALAND LABORATORY STANDARDS INSTITUTE (CLSI). Performance standards for antimicrobial disk susceptibility tests. 8.ed. Wayne: Clinical and Laboratory Standards Institute, 2003a. (Approved Standard M2-A8).

CLINICALAND LABORATORY STANDARDS INSTITUTE (CLSI). Methods for dilution antimicrobial susceptibility tests for bacteria that grow aerobically. 6.ed. Wayne: Clinical and Laboratory Standards Institute, 2003b. (Approved Standard M7-A6).

CLINICALAND LABORATORY STANDARDS INSTITUTE (CLSI). Method for antifungal disk diffusion susceptibility testing for yeasts. Wayne: Clinical and Laboratory Standards Institute, 2009. (Approved Guideline M44-A2). 
CORDEIRO, C. H. G.; SACRAMENTO, L. V. S.; CORREA, M. A.; PIZZOLitTO, A. C.; BAUAB, T. M. Análise farmacognóstica e atividade antibacteriana de extratos vegetais empregados em formulação para a higiene bucal. Braz. J. Pharm. Sci., v.42, n.3, p.395-404, 2006.

DUARTE, M. C. T.; FIGUEIRA, G. M.; SARTORATTO, A.; REHDER, V. L. G.; DELARMELINA, C. Anti-Candida activity of Brazilian medicinal plants. J. Ethnopharmacol., v.97, n.2, p.305-311, 2005.

FARMACOPÉIA BRASILEIRA. 4.ed. São Paulo: Atheneu, 1988. 392 p.

FIÚZA, T. S.; SABÓIA-MORAIS, S. M. T.; PAULA, J. R.; TRESVENZOL, L. M. F.; PIMENTA, F. C. Evaluation of antimicrobial activity of the crude ethanol extract of Eugenia uniflora L. leaves. Rev. Ciênc. Farm. Básica Apl., v.29, n.3, p.245-250, 2008.

FOLIN, O.; CIOCALTEAU, V. On tyrosine and tryptophane determination in proteins. J. Biol. Chem., v.73, n.2, p.627$649,1927$.

GABRIELSON, J.; HART, M.; JARELÖV, A.; KÜHN, I.; MCKENZIE, D.; MÖLLBY, R. Evaluation of redox indicators and the use of digital scanners and spectrophotometer for quantification of microbial growth in microplates. J. Microbiol. Methods, v.50, n.1, p.63-73, 2002

HILliER, S. L.; KROHN, M. A.; KLEBANOFF, S. J.; ESCHENBACH, D. A. The relationship of hydrogen peroxide-producing lactobacilli to bacterial vaginosis and genital microflora in pregnant women. Obstet. Gynecol., v.79, n.3, p.369-373, 1992.

ISAAC, V. L. B.; CEFALI L. C.; CHIARI, B. G.; OLIVEIRA, C. C. L. G.; SALGADO, H. R. N.; CORRÊA, M. A. Protocolo para ensaios físico-químicos de estabilidade de fitocosméticos. Rev. Ciênc. Farm. Básica Apl., v.29, n.1, p.81-96, 2008.

LORENZI, H. Árvores brasileiras: manual de identificação e cultivo de plantas arbóreas nativas do Brasil. 3.ed. Nova Odessa: Instituto Plantarum, 2000. v.1.
MONTEIRO, J. M.; ALBUQUERQUE, U. P.; LINS NETO, E. M. F.; ARAÚJO, E. L.; ALBUQUERQUE, M. M.; AMORIM, E. L. C. The effects of seasonal climate changes in the Caatinga on tannin levels in Myracrodruon urundeuva (Engl.) Fr. All. and Anadenanthera colubrina (Vell.) Brenan. Rev. Bras. Farmacogn., v.16, n.3, p.338-344, 2006.

OCAÑA, V.; SILVA, C.; NADER-MACÍAS, M. E. Antibiotic susceptibility of potentially probiotic vaginal Lactobacilli. Infect. Dis. Obstet. Gynecol., v.2006, p.1-6, 2006, doi: 10.1155/idog.2006.18.182.

ORDOÑEZ, A. A. L.; ORDOÑEZ, R. M.; ZAMPINI, I. C.; ISLA, M. I. Design and quality control of a pharmaceutical formulation containing natural products with antibacterial, antifungal and antioxidant properties. Int. J. Pharm., v.378, n. 1-2, p.51-58, 2009.

PESSINI, G. L.; HOLETZ, F. B.; SANCHES, N. R.; CORTEZ, D. A. G.; DIAS FILHO, B. P.; NAKAMURA, C. V. Avaliação da atividade antibacteriana e antifúngica de extratos de plantas utilizados na medicina popular. Rev. Bras. Farmacogn., v.13, supl.1, p.21-24, 2003.

PINTO, T. J. A.; KANEKO, T. M.; OHARA, M. T. Controle biológico de qualidade de produtos farmacêuticos, cosméticos e correlatos. 2.ed. São Paulo: Atheneu, 2003. $325 \mathrm{p}$.

REICHLING, J.; LANDVATTER, U.; WAGNER, H.; KOSTKA, K. H.; SCHAEFER, U. F. In vitro studies on release and human skin permeation of Australian tea tree oil (TTO) from topical formulations. Eur. J. Pharm. Biopharm. v.64, n.2, p.222-228, 2006

REID, G.; BRUCE, A. W. Urogenital infections in women: can probiotics help? Postgrad. Med. J., v.79, n.934, p.428-432, 2003.

ROESSLER, W. G. Methods of testing antiseptics. In: BLOCK, S. S. Desinfection, sterilization and preservation. 3.ed. Philadelphya: Lea \& Febiger, 1983. p.100-106.

SCHRAMM, G. Reologia e reometria: Fundamentos teóricos e práticos. 2.ed. São Paulo: Artliber, 2006. 260 p.

SERAFIN, C.; NART, V.; MALHEIROS, A.; CRUZ, A. B.; MONACHE, F. D.; GETTER, M. L. A.; ZACCHINO, S.; CECHINEL FILHO, V. Evaluation of the antimicrobial effects of P. glomerata (Myrtaceae). Rev. Bras. Farmacogn. v.17, n.4, p.578-582, 2007. 
SHAPIRO, S.; GIERTSEN, E.; GUGGENHEIM, B. An in vitro oral biofilm model for comparing the efficacy of antimicrobial mouthrinses. Caries Res., v.36, n.2, p.93100, 2002.

SILVA, M. T. G.; SIMAS, S. M.; BATISTA, T. G. F. M.; CARDARELLI, P.; TOMASSINI, T. C. B. Studies on antimicrobial activity, in vitro, of Physalis angulata $\mathrm{L}$. (Solanaceae) fraction and physalin B bringing out the importance of assay determination. Mem. Inst. Oswaldo Cruz, v.100, n.7, p.779-782, 2005.

SOBEL, J. D. Bacterial vaginosis. Anпи. Rev. Med., v.51, p.349$356,2000$.

SOUZA, G. C.; HAAS, A. P. S.; von POSER, G. L.; SCHAPOVAL, E. E. S.; ELISABETSKY, E. Ethnopharmacological studies of antimicrobial remedies in the south of Brazil. $J$. Ethnopharmacol., v.90, n.1, p.135-143, 2003.

SOUZA-MOREIRA, T. M.; MOREIRA, R. R. D.; SACRAMENTO, L. V. S.; PIETRO, R. C. L. R. Histochemical, phytochemical and biological screening of Plinia caulifora (DC.) Kausel, Myrtaceae, leaves. Rev. Bras. Farmacogn., v.20, n.1, p.48-53, 2010.
SUFFREDINI, I. B.; PACIENCIA, M. L. B.; NEPOMUCENO, D. C.; YOUNES, R. N.; VARELLA, A. D. Antibacterial and cytotoxic activity of Brazilian plant extracts - Clusiaceae. Mem. Inst. Oswaldo Cruz, v.101, n.3, p.287-290, 2006.

WEBB, B. C.; THOMAS, C. J.; WILLCOX, M. D.; HARTY, D. W.; KNOX, K. W. Candida-associated denture stomatitis. Aetiology and management: a review. Part 1. Factors influencing distribution of Candida species in the oral cavity. Aust. Dent. J., v.43, n.1, p.45-50, 1998.

WEBB, B. C.; THOMAS, C. J.; WHITTLE, T. A 2-year study of Candida-associated denture stomatitis treatment in aged care subjects. Gerodontology, v.22, n.3, p.168-176, 2005.

XHAUFLAIRE-UHODA, E.; MACARENKO, E.; DENOOZ, R.; CHARLIER, C.; PIÉRARD, G. E. Skin protection creams in medical settings: successful or evil? J. Occup. Med. Toxicol., v.3, n.1, 2008. Available at: http://www. springerlink.com/content/0540305wr210487v/fulltext.pdf. Accessed on: 20 may 2011.

Received for publication on $11^{\text {st }}$ November 2010 Accepted for publication on $14^{\text {th }}$ April 2011 
